\title{
After Trauma of Gaokao
}

\author{
Yanping Lu \\ 191 Binhai Middle Road, Yantai, Shandong Province, PRC \\ 1735337068@qq.com
}

Keywords: trauma, Gaokao, aversion, burnout, brain-racking

\begin{abstract}
The paper addresses the problem of aversion to learning popular in college as after trauma of Gaokao. After a survey of the situation per se and the cause-effect analysis, some remedy recurring to technology and mentality is suggested.
\end{abstract}

\section{Status quo}

As a EFL teacher at work for virtually 30years at an institute of finance and economics, I often feel a sense of failure rather than achievement. Every year, upon admission and freshmen registration, I expect fresh-faced, ambitious and conscientious freshmen to crowd into the library for books they have been hungered to read, sneak into classes and lectures beyond their fields to extend their scope of knowledge, strive for their greatness and grant me that sense of achievement as a teacher. But sooner than later I am disappointed and frustrated by their ennui, passivity and even resistance to learning.

As a matter of fact, the first year is usually not bad. The freshmen are not yet that "fresh." Fresh from the trauma of Gaokao, the national entrance examination for college, they are not relaxed for some time from the strictly-disciplined habit and behavior. They keep the high school tradition of hard work and obedience. Upon registration, there are so many extra-curricula and activities to participate. To start with college, they undergo a quasi-military training, a typically Chinese style of college orientation, for two or three weeks, to reinforce discipline and obedience. To keep them busy, there are all kinds of activities ranging from honors day, club member recruitment, vaccine injection, to freshmen basketball match. A packed schedule day in and day out; even if they do not participate, they are to be there to watch and cheer. There are special rules and regulations for them: early morning exercise and late evening self-study sessions, all in collective; regular roll-call, OWL penalty, etc. Most freshmen do not know what colleges generally do to people or what they are supposed to do in college, so they play safe by observing rules. Class attendance is out of question as they don't know what else to do. They listen to the teachers and literally take notes of what the teachers say in class, trying hard not to doze off. They would not seek out learning or take active part in the subject matter, but they expect to do homework. If a teacher assign no written homework after class or do not grade their work on a daily basis, they feel uncomfortably at a loss. Optional reading is usually left undone. Anyhow, the freshman year goes easy, carefree, aimless, painless and perplexed.

After a year's adjustment and familiarization, and after two finals, many become sophomore in the sense that they find out what college is and what it is like to be a colleger. The revelation dawns on them that college is a place where you practice hedonism, anarchism, and total freedom. In classroom where no roll-call is mandated you see large scale of absence, large scale of playing at he cell phones under or even on top of desks if not watched closely and checked frequently, a large scale of dozers-off or sleeping logs, and a large scale of cheating if the watch dogs are not making rounds as vigilant dogs. If they can get away with it, filing out of the test room without being caught, their joy is almost uncontainable, like something to be celebrated with dancing and singing and feasting. To some teachers' great distress, the clips of cheating tips can fill half a wastepaper basket after some test!

The junior years brings them back to track a little bit, since their specialized courses are well in 
advance, some going endgame. Those who are determined to engage in postgraduate programs set out again to work hard, and harder than they did Gaokao. And those who want to take the state civil servant test, known as Guokao, or various other tests for various certificates, begin to study or cram. You see early raisers by the lake reciting books, and late candle burners keeping themselves awake drinking strong doses of coffee. Classroom performance may suffer, though, for everyone seems to find their own things to pursue.

The senior year get by in a blur, with practically no regular classes to attend any more. Many go on and off campus for internships and job hunting while managing to finfish their dissertation papers. And then comes the commencement.

That is the typical tour of college for most undergraduates.

\section{Prior to College}

Why the collapse at a time of success much sought after with their decades of hard work and heroic struggle at Gaokao? How come that the will to learn and love of knowledge and wisdom break down and out all of a sudden?

The tragic truth is, that love and will has long been quenched, and if any more survived, burns out at Gaokao.

Let's trace their road to college, and compare it with other will and ways. Things taught at elementary and secondary schools in the west are of the basics, with difficulty increasing slowly and gradually, allowing students to acquire the common knowledge and common sense and at the same time maintain their fascination and room for later development and further study, maybe all the way through college to postgraduate and doctorate, where scholastic study commence in earnest, so it is not surprising that an eight-grader could not say out right how many cakes there are in a tray where there are four rows by six each; they might count them with an index finger one by one until they come to the sum total. But in China, we are virtually advanced by 3 years in science curricula, that is to say, our four-graders are at the same level as the seven-graders in the US., and our junior high schoolers are learning things that their senior high are teaching. That's why Chinese students are so damned diligent and academically advanced, in test, so to speak.

Another thing to compare is about the test. Here I take an example of biology of senior high. About the chapter of gene mutation, the national standard textbook is explicit: "A gene mutation is a permanent alteration in the DNA sequence that makes up a gene, such that the sequence differs from what is found in most species." With a case of sickle-cell amenia and some diagrams, it's quite comprehensible, and the test questions are to the point:

1. What is the primary cause of sickle-cell amenia?

2. Is it hereditary?

Both American and Chinese, with moderate senses, may understand and answer them. (Of course those eager learners may go on to explore and experiment, and find more by further reading or online surfing.) But Chinese test questions will not stop there. Now try these:

1. There are 3 groups of hereditary diseases: of monogenic inheritance, polygenic inheritance, and chromosome aberrant inheritance, respectively. How do the following diseases identify with the 3 groups?

(1)primary hypertension (2) Down's syndrome, (3) Cystic fibrosis, (4)Juvenile diabetes, (5)Gonadal dysplasia (6) sickle-cell amenia, (7) asthma, (8) cri du chat syndrome, (9) congenital deaf-mutism
A. (3)(6)(9) (2)(5)(8) (1)(4)(7)
B. (3)(6)(9) (1)(4)(7) (2)(5)(8)
C. (1)(4)(7) (2)(5)(8) (3)(6)(9)
D. (2)(5)(8) (3)(6)(9) (1)(4)(7)

2. The following are the sequence of amino acids of a normal gene for a certain protein in nature and the amino acid sequences of its 3 mutated genes.

Normal gene: arginine phenylalanine Leuline Threoline, Proline

Mutated gene1 arginine phenylalanine Leuline Threoline, Proline 
Mutated gene2 arginine Leuline Leuline Threoline, Proline Mutated gene3 arginine phenylalanine Threoline Tyrosine alanine

By comparing the amino acid sequences, tell what happened in the DNA molecules of these three mutated genes.

A In Mutated gene 1 and 2 one nucleotide is substituted, in Mutated gene2 one nucleotide is added

$\mathrm{B}$ In Mutated gene 2 and 3 one nucleotide is substituted, in Mutated gene 1 one nucleotide is added

$\mathrm{C}$ In Mutated gene 1 one nucleotide is substituted, in Mutated gene2 and 3 one nucleotide is added

D In Mutated gene 2 one nucleotide is substituted, in Mutated gene1 and 3 one nucleotide is added

Isn't it brain-racking! It takes much expertise to get that. And there are hundreds or even thousands of questions like these for homework and tests. For non-specialists of this field, it takes great brain and pain to do and remember all these details, yet all comes to no point in the end for most would be forgotten after Gaokao. Many students don't go in for life study and those who major in biology would start everything all over again in college.

It is said that in the US tests are designed to prove what you know or what you have learned, in China tests are obviously to confuse you, to mislead you, to find fault with you, to intimidate you, to frustrate you and to fool you until you prove yourself the fool you are. Those who survive the trauma of Gaokao are genius or geeks so impossibly good at memory and test-taking that they come as something virtually inhuman, yet soon afterwards go their own way of annihilation.

It is true that truth comes the hard way to triumph over falsehood. Say, people used to believe that thinking occurs in the heart instead of in the brain. But is it necessary to take people's heart, brain, liver and kidney out to test which is the sit of intelligence now that we have long found out?? Thomas Edison had tried 1000 materials to find out the right one for the filament of light bulb. Must we mix it up with those 999 materials in a heap once again to come up with the right thing? What a waste! Why can't we use the brain and time and energy to explore and experiment, to seek more truth, such as: does the skin memorize things? Or is there pre-life and after-life, genetically speaking?

But what should have been done are seldom done in the course of school. Many a case studies, comparative experiments, and researches and field work remains virtual projects, never practiced. To save time, teachers simply tell them the process and the results. Once I paged through my daughter's chemistry book and happened to land on polyethylene and polythene fiber, about its washing and ironing temperature, I felt so happy for her that they should learn such useful and practical things about everyday life. So I set aside lots of clothes, detergent and iron for the washing and ironing when she came home from school so that we might discuss the matter and I might learn from her. But upon her return, at the stack of washing she sneered and said, "Got no time. So much homework to do. We never need to do hand-on projects. Our teachers hand everything onto us. We need only to memorize everything."

Why do we have to make it so hard? Can't we make learning enjoyable and meaningful? Of course most people can't. They can not afford to have fun and enjoy learning. It is far from enough to learn about the basic things about everything. One has to be able to remember more facts, solve more complicated problems, and do better in the brain-wracking tests to the point of mental, physical and intellectual burnout to beat other three or four students to get into senior high and later on to college and to be ensured of a better life..

\section{After trauma}

If pre-college years are like purgatory, Gaokao is the devastating trauma. Those months before the exams turn students into learning robots working 16 or more hours a day, with only 4 or 5 hours of sleep a night, stuffing and going over all things accumulated in human history in their brain and taking practice tests and simulation exams on a daily basis.

Then comes Gaokao, four tests in two days. On those days the world seems to stop hushed to make way for the greatest event in the nation which may determine these young people's fate, practically a vital battle of "to be, or not to be."

To a lot of people that is a battle once for all, hence the outcry: "It is the last time that the brain 
ever works, then to hell with it!” And true as it is, after Gaokao, students are physically, mentally and intellectually burned out, and they literally tear and burn their textbooks and notes and homework, throw the paper scraps into the air, sing and dance around the bonfire of books, crazy like long-imprisoned slaves at last set free.

So when they at long last get to college they think the have arrived and they get the chance to empty themselves to make room for fun, comfort and pleasure they missed prior to college. Sleeping late, cutting classes, skipping homework and even cheating, if not caught on the spot, are no longer sins, and in time they obtain their diploma as long as they pass the finals. It was the goal reached.

Yet there have been a lot of complaints and blames on colleges for the hard-to-find employment of university graduates and their low income in the first few years at work compared with manual labors and in contrast to the price they paid to a university education. True, some young people from poverty-stricken families in some poor areas will not pay off the debts and loans for years to come. Some people begin to ask, "Is it worth going to a university?" One of the deputies to the People's Congress even made a proposal to discourage the poor from going to college after assessing the gain and loss.

It is not the students to blame for all this, since there seems nothing significant to learn, especially in colleges of arts and humanities. As we catch up with the world, we become too ambitious in education. We tend to teach in elementary school things that should be taught at middle school and high school curricula in turn take over things that should be studied specially at college level, hence the enormous pressure prior to Gaokao and the lax and idleness in college. At college, biology majors would probably find that some courses are repeating what they have known, only in more detail; advanced math is not that far advanced at that.

\section{Remedy}

To combat the downing trends, our college mandated stricter rules and regulations: "Students who miss classes for six times will be disqualified for the final exam and fail the course." "Students who use cell phones will get 30\% discounted from their classroom performance." "Those who cheat or facilitate cheating will have demerit records and be expelled if the case is of grave consequence." And teachers have to have the roll call every time and frequently stop to check the phony. But the students can always beat the system and find their way out. They play games on the phone under cover; they go to sleep in class in the back rows; they cheat without being caught. Anyway, you can take the cow to water, but you can not make it drink.

Punishment is never the remedy or spur to learning and achievement. It's time to make a change. And there is IT, the Web, the most drastic revolution in the 21st century, which is bringing dramatic changes to college education. With distance education, on-line courses, virtual classrooms, school in the cloud, flipped class, MOOC, so many ways to learning are available for anyone, any time and at any place. It is just based on the circumstances that blended learning integrating face-to-face instruction and online teaching provides a new way in education.

Amazing as all these could bestow, I feel the irony of it in person. In April this year a High-Tech education exhibition was held on campus. There were all kinds of advanced fidgets and software and systems, e-learning, i-studio, cloud classroom, etc. etc. I was quite impressed by one called "rain classroom," in which students will be under monitor and surveillance that their doings will be literally seen and recorded, say if they play games while leaving the study interface minimized. I admired all this, but at the same time I can't help feeling sad about the fact that with such good things at hand, with so advanced technology, students should be coerced to learn!

The irony is the more advanced these teaching facilities, the less advancing students are. All these seem to indicate that people 's urge for learning are on the wane. People are born with an instinctive and unquenchable curiosity for knowledge, which distinguishes human beings from other animals and helps people evolve and advance to the highest being. Yet we are losing it, along 
with our natural pleasure of learning. As Gilbert Highet observed, “As most schools are set up today, learning is becoming compulsory. It is an Ought, or even worse, a Must, enforced by regular hours and strict discipline. And the young sneer at the Oughts and resist the Musts with all their energy. The feeling often lasts for a life time. To many learning appears to be a surrender of their will to external direction, a sort of enslavement."

If a man can not feel the joy and happiness of learning and researching and discovering and creating, the fraternity of campus, the uplifting and sublimity as a homo sapien distinguished from other animals, what is it to be man? Let him compare himself to wild animals, or think of the child labors at 12 who did manual work in underground factories for 14 hours a day!

Robert M. Hutchins holds, "the aim of liberal education is human excellence.... Its object is the excellence of man as man and man as citizen. It regards man as an end, not as a means, and it regards the ends of life, and not the means to it. For this reason, it is the education of free men. Other types of education or training treat men as means, to some other end, or at best concerned with the means of life, with earning a living, and not with its ends."

Man is the end. Knowledge itself is the end. Education is the end. Man would not want anything else out of an education because it is good and happiness enough when man could get out of ignorance, and what is more, when he stands the chance to creation. J.A. Comenius put it quite plainly when he advocated the concept of "pansophy", universal education is possible "not so much to make men learned as to make them wise.... We want all men to be pansophists because then they could achieve perfection if they so desire it.” If happiness and self-fulfillment is the end for man, an educational institute should be the place where the ends meet the means, hence the place where people are at their happiest. A university is a means and an end in one, not just an access to success or gain. It is an insignia not of status, but of state, a state of being in a divine kingdom of learning, a state of intellectual happiness. To regain students' love for learning and keep that state of bless and bliss is of first priority.

For the love for learning, for the happiness of man, I suggest that learning be made easier and approachable at kindergartens, elementary school, high school and college, a pleasure instead of drudgery, a way of life at that instead of a way of making a living, an uplift toward good and perfection in stead of a step-up to worldly success or gain. For that the test-oriented educational system should be abolished at the baseline just as we abolished the imperial examination system! Schools should teach in accordance of students' aptitudes and students should achieve for themselves on the merit of their attitudes. If a man can not be an Einstein or a Newton, let him just get to know them. If it is vocational skills that a man is seeking, let him serve apprentice to a workshop. If someone has got an artistic turn of mind, family, school and society should help and support him or her to achieve the greatest they could. Education should be a common cause for all.

Why should we be so anxious to achieve quick success and get instant benefits in education? If China is said to be on the way toward prosperity, people should have faith and belief in our future where everyone will achieve happiness in his or her life.

\section{References}

[1] John Henry Newman. The Idea of a University. Longmans Green, and Co. 1907.

[2] Robert Maynard Hutchins. The Higher Learning of America. Yale University Press. 1936.

[3] Lesley Saunders. Educational Research and Policy-Making. Routledge: Taylor \& Francis Group. New York and London. 2007.

[4] Joel Spring. American Education. McGraw-Hill Inc. 1994.

[5] John Edward Sadler. J.A. Comenius and The Concept of Universal Education. Routledge: Taylor \& Francis Group. London. 2007. 